УДК 655.3.026.27:655.3.025:676.263.4:001.4.001.5

\title{
ТЕХНОЛОГІЧНІ ОСОБЛИВОСТІ ТА СИСТЕМАТИЗАЦІЯ СПОСОБІВ ТЕРМОТРАНСФЕРНОГО ДРУКУ
}

() О. М. Нечипорчук, Т. В. Розум, к.т.н., доцент, НТУУ “КПІ», Київ, Україна

Проанализированы технологические особенности термотрансферной печати, рассмотрены устаревшие и современные способы печати, обобщены и систематизированы их разновидности, выделены основные составляющие технологических процессов, характеристик материалов и оборудования.

The technological features of heat transfer printing are analysed, the out-of-date and modern methods of printing are considered, generalized and systematized their variety, the basic components of technological processes, descriptions of materials and equipment are singled out.

\section{Постановка проблеми}

Способи термотрансферного друку існують досить тривалий період часу, переважна більшість $з$ яких інтегрувала зі старих, давно існуючих різновидів друку, адаптувавшись під сучасні прогресивні технології. Тому так склалося, що видів термотрансферного друку існує багато, а варіантів їх назв - ще більше. Тому часто постають проблеми у розумінні й невизначеності у приналежності певних технологічних операцій до різних процесів.

\section{Мета роботи}

Дослідити особливості технологічних процесів новітніх способів термотрансферного друку, проаналізувати варіанти їх назв, з'ясувати найбільш широко використовувані з них, дослідити, які 3 назв найбільше від- повідають технологічним особливостям кожної з технологій, систематизувати різновиди термотрансферного друку за технологічними процесами, характеристиками матеріалів та обладнання, що мають місце в кожному способі друку.

\section{Аналіз попередніх досліджень}

Загалом термотрансферний друк можна визначити як технологію перенесення зображення з проміжного носія на виріб під дією підвищеної температури й тиску. Свого часу подібні способи формування зображення вже досліджували, зокрема у КФ ВНДІ поліграфії, розробляючи перебивні зображення (декалькоманія) [1], термоприклеювальні аплікації [2]. Під перебивними зображеннями (англ. transfer $[3,4])$ розуміють нане- 
сені на поверхню проміжного носія (полімерної чи паперової основи з низькою адгезією [5]) фарбувальні речовини. Вони покриті чутливим до тиску клеєм $[6,7]$, і мають властивість під впливом тиску повністю відокремлюватись від основи і переходити на іншу поверхню. Для нанесення фарби на основу застосовували переважно трафаретний та в меншій мірі офсетний друк. Перебивні зображення знайшли широке застосування завдяки розробленим технологічним процесам, що характеризуються швидким перенесенням та міцним закріпленням зображень на виробах з металу, скла, пластмас, дерева та ін.

Дещо видозміненими можна вважати сучасні термотрансферний, сублімаційний термотрансферний друк, пластизольні трансфери, термоперенесення текстильними плівками, тощо, які розвиваються з кожним роком [8]. Загалом багато з них адаптувались під сучасні способи друку, що характеризуються оперативністю та меншою собівартістю продукції при малих накладах.

\section{Результати проведених досліджень}

Під термотрансферним друком розуміють досить багато різноманітних технологій [9], що відрізняються за видами фарбувальних речовин та способів їх нанесення, проміжних носіїв, обладнання для термічного припресування й перенесення зображення на виріб, тощо.

Для того, щоб виділити основні характеристики термотрансферного друку, розглянемо його різновиди.

\section{Термографія 1}

Існує декілька різновидів цього способу друку, які загалом полягають у використанні проміжного носія з нанесеною на нього фарбувальною речовиною. Термографія поділяється на пряму термографію та термографію перенесення [10], які часто називають термодруком і термотрансферним друком відповідно, що зумовлює певні складнощі у розумінні, адже загальне поняття термотрансферного друку не дає чіткого окреслення виду технологій, що використовуються.

В обох випадках застосовується спеціальний папір - фарбувальна стрічка (ріббон) шириною до декількох десятків сантиметрів, довжиною до декількох сотень метрів. У прямій термографії такий папір містить на своїй поверхні спеціальні речовини, які плавляться під впливом підвищеної температури, що надходить від термоголівки термопринтера і зафарбовують папір (рис. 1, а). Таким чином, готовий продукт - це фарбувальна стрічка із зображенням, що утворилося на його поверхні під дією температурних факторів.

1Варіанти назви технології виробниками матеріалів та обладнання: Thermal direct printing (TallyGenicom, ZIH Corp) - пряма термографія; Thermal transfer printing (ZIH Corp, Datamax, Citizen, Fargo), Thermal Wax Transfer (Shinko, Seiko, Fargo) Thermal Mass Transfer (Kyocera) - термографія перенесення. 
Рис. 1. Термографія: а) пряма термографія: 1 - матеріал-основа, 2 - термочутливе покриття, 3 термоголівка, 4 - утворене зображення; б) термографія перенесення: 1 - матеріал-основа, 2 - фарбувальний шар, 3 - носій фарбувального шару, 4 - термоголівка, 5 - перенесений шар фарби

Термографія перенесення поділяється на термоперенесення і термосублімацію. В обох цих випадках фарбувальна стрічка має вигляд паперу з нанесеним шаром фарбувальної речовини, яка переноситься на виріб при нагріванні стрічки в місцях її дотику з поверхнею виробу (рис. 1, б). Відмінність полягає лише у властивостях фарбувальної речовини. Термоперенесення також називають термовосковим перенесенням через його восковий фарбувальний шар [11].

Порівнюючи пряму термографію та термографію перенесення з іншими різновидами термотрансферного друку, варто зазначити, що в першій технології відбувається лише формування зображення, а в другій - перенесення фарбувальної речовини з одного матеріалу на іншій на відміну від інших способів, де проміжний носій задруковується на електрографічних (лазерних ), струминних та інших друкарських апаратах, а потім відбувається перенесення надрукованого зображення на виріб. Тому розглянуту другу технологію, називати термотрансферним друком не досить
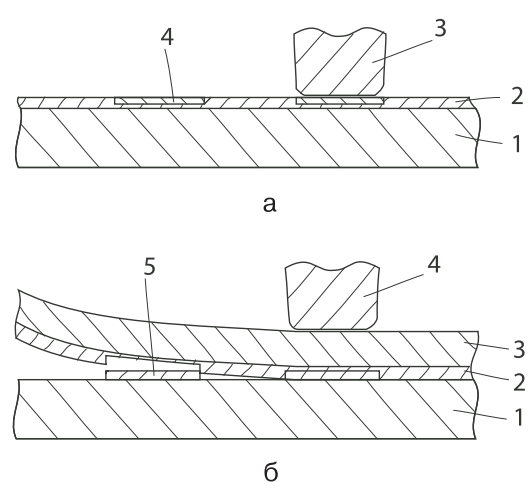

правильно, більш прийнятними назвами $€$ термоперенесення, термовоскове перенесенням або термотрансфер (оскільки перенесення і трансфер це одне і те ж), але з іншого боку під трансферами зазвичай розуміють дещо іншу технологію, яка буде описана далі, або ж називати термографією перенесення, але знов таки графія (від грецьк. grapho) теж означає друк. Загалом, слід зазначити, що чітко визначеної назви цієї технології немає. Та й сфера застосування цього різновиду друку обмежується формуванням зображень на касових чеках, цінниках, квитанціях, найпростіших етикетках.

\section{Пластизолеві трансфери}

Ще один спосіб термотрансферного друку, який здебільшого не має широкого застосування - це пластизолеві трансфери [12]. За технологією пластизолеві трансфери майже нічим не відрізняються від перевідних зображень: за допомогою трафаретного друку пластизолевими фарбами здійснюється нанесення зображення на папір, що пропускається через сушарку, де фарба має дещо підсохнути. I 
вже у термопресі відбувається перенесення зображення на виріб під впливом температури й тиску.

Виділяють два різновиди цього способу формування зображення - трансфери гарячого (hot split) і холодного (cold peel) зняття паперу з виробу. Трансферні папери мають спеціальне покриття, що збільшує стабільність розміру, стійкість до скручування; є бар'єром між фарбою і папером (для запобігання проникненню пластифікатора в папір і зберігання трансферу).

Проте не залежно від видів трансферів, після зняття з виробу частина фарби все-таки залишається на папері. Тому друкування наведеним вище способом робить проблематичним нанесення зображень, що містять дрібні деталі та великі плашки [13]. 3 урахуванням цього можливо використовувати термоклейові порошки, що активуються при нагріванні і дозволяють приклеювати фарбу до виробу, або ж попередньо наносити на папір пластизолевий шар (прозорий або білий), що буде прилипати безпосередньо до тканини, і до якого прилипатиме фарба. Останній варіант найбільш нагадує термотрансферний друк (буде розглянутий нижче), де використовується папір, покритий полімерним шаром.

Загалом друкування пластизолевих трансферів безпосе- редньо залежить від трафаретного друку і передбачає використання трафаретних сит, що не дає тієї оперативності і повноколірності, якою характеризуються інші термотрансферні технології.

Ще одним послідовником перевідних зображень можна вважати термотрансферний друк, який має досить широке застосування. Під термотрансферним друком найчастіше розуміють саме цей спосіб формування та перенесення зображень на виріб.

\section{Термотрансферний друк 2}

Цей спосіб друку полягає в задруковуванні проміжного носія, 3 якого в подальшому під дією підвищеної температури й тиску відбувається закріплення зображення на поверхні виробу [14].

\section{Технологія}

На першому етапі необхідно створити макет із зображенням, яке повинно бути перенесене на продукт. Потім відбувається друкування в непрямому (дзеркальному) або прямому режимі (залежно від типу паперу; можливо також зробити виворітний макет) на робочій стороні проміжного носія - термотрансферного паперу, що складається з полімеру та паперової основи [11].

У випадку непрямого друку папір відразу накладається на

\footnotetext{
2Варіантів назви даної технології багато, починаючи від термодруку, закінчуючи термоперенесенням, але, розглянувши, як її називають самі виробники устаткування і матеріалів, можна сказати, що приведена вище назва найбільш прийнятна: heat transfer (Adkins); heat transfer, heat seal (Insta); transfer printing (TheMagicTouch), digital transfer printing (Forever), Thermotransfer, transfer (Lomond).
} 
виріб задрукованою стороною і під впливом нагрівання й тиску в термопресі фарба з прозорим полімерним шаром переходить на поверхню виробу (рис. 2). Таким чином зображення переходить з виворітного в пряме, а полімерний шар накриває фарбувальну речовину і захищає ії від фізико-хімічного впливу. Після цього паперова основа знімається або відразу, або після її охолодження.

У випадку прямого нанесення зображення на термотрансферний папір після задруковування паперу при необхідності відбувається його прорізування на плоттері. Потім з нього відра-

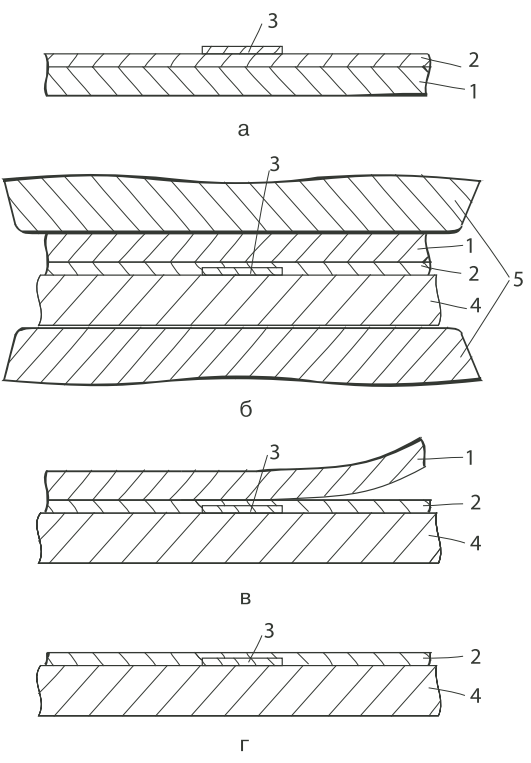

Рис. 2. Термотрансферний друк на світлих поверхнях: а) трансфер: 1 - матеріал-основа, 2 - полімерний шар, 3 - фарба;

б) перенесення зображення у пресі: $1-3-$ див. (а), $4-$ виріб, 5 - термопрес; в) відокремлення основи: $1-4-$ див. (б); г) готовий виріб: 2-4 - див. (б) зу знімається паперова основа і вже полімер (непрозорий, звичайно білого кольору) з фарбувальною речовиною незадрукованою стороною розміщується на поверхні виробу в термотрансферному пресі. Під дією температури й тиску полімерний шар з фарбою вплавляється в поверхню виробу (рис. 3).

\section{Матеріали}

у технологічному процесі термотрансферного друку в якості матеріалів беруть участь термотрансферний папір та фарбувальні речовини. Для формування зображення застосовують тонери для електрографічного
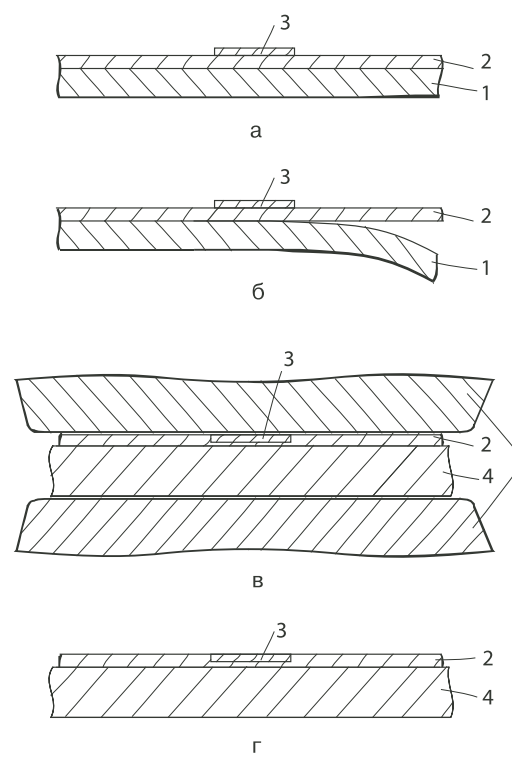

Рис. 3. Термотрансферний друк на темних поверхнях: а) трансфер: 1 - матеріал-основа, 2 - полімерний шар, 3 - фарба; б) відокремлення основи: $1-3-$ див. (а); в) перенесення зображення у пресі: 2, 3 - див. (а), 4 - виріб, 5 - термопрес; г) готовий виріб:

$$
\text { 2-4 - див. (в) }
$$


(лазерного) друку, рідкі фарби для струминного друку, також іноді використовують трафаретні фарби.

Основним матеріалом, який дозволяє переносити зображення на поверхні виробів $€$ проміжний носій, в якості якого використовують термотрансферний папір. Завдання проміжного носія - прийняти фарбувальну речовину, а потім віддати іï̈ в термопресі поверхні виробу. Термотрансферний папір має вигляд паперу (основи), на який нанесено подвійний шар полімеру. Один шар утримує фарбувальні речовини на своїй поверхні. Інший - не офарбовується і перешкоджає проникненню фарбувальних речовин в паперову основу. Сама ж паперова основа виконує роль транспортного матеріалу, за допомогою якого можливий друк на термотрансферному папері. Вона служить тільки для утримання полімерного шару в процесі нанесення на нього зображення в друкарських апаратах [15].

$€$ велика кількість видів термотрансферного паперу від різних виробників. Вибір залежить від друкарського апарату, що застосовується, і поверхні, на яку буде наноситись зображення. В основному, розрізняють від 3 видів термотрансферних паперів: для світлого текстилю, для темного текстилю, для твердих поверхонь та ін.

Папери для темного текстилю відрізняються від аналогічних для світлого тим, що паперова основа в них може легко відділятися. У подальшому перенесення відбувається без її участі. Це пов'язано з тим, що на сьогоднішній день відтворювати білий колір на задруковуваному матеріалі або не можна, або дуже складно. Тому полімер має біле забарвлення і відтворює білий колір на кольорових поверхнях. Основа паперів для світлого текстилю від'єднується після прогрівання в пресі, а полімерний шар для таких паперів - прозорий.

Загалом виготовляють термотрансферні папери форматів А3 та A4.

\section{Обладнання}

Для формування зображення на проміжному матеріалі використовується переважно повноколірний електрографічний (лазерний) і струминний друк. Також існують деякі види термотрансферного паперу, які можна задруковувати за допомогою трафаретного та сухого офсетного друку, але вони рідко використовуються.

Не будь-які друкарські апарати підходять під кожен вид проміжного носія. Це стосується переважно термотрансферного паперу для світлого текстилю та твердих поверхонь, оскільки при друкуванні на трансферному шарі температура закріплення тонеру деяких принтерів перевищує температуру плавлення полімеру. Тому відбувається налипання термотрансферного паперу на вали принтера.

Що стосується термопресів - вони бувають різних форматів і характеризуються різними можливостями. Існують термопреси для роботи з простими (пласкими) та складними (круглої форми) поверхнями. 
Термопрес забезпечує рівномірний нагрів з температурою від 120 до $200{ }^{\circ} \mathrm{C}$ і щільний притиск розміщеної поверхні матеріалу. Виріб витримується у пресі певний час (від 5 секунд до декількох хвилин), після чого він готовий до використання.

У термотрансферному друці зазвичай використовують невеликі термопреси, здатні працювати з форматами термотрансферних паперів A3 і A4.

\section{Застосування}

Технологія термотрансферного друку дозволяє швидко перенести повноколірні зображення на різні матеріали, такі як: текстиль, скло, кераміка, пластик, дерево та багато ін. Цей метод економічно виправданий при нанесенні повноколірних зображень при невеликих накладах.

Якість продукції залежить від ряду чинників: температури, рівномірності тиску по всій площині поверхні, вологості і часу дії на виріб. Найчастіше ці параметри індивідуальні і вимагають оптимізації під конкретний матеріал [16].

Технологія термотрансферного друку визнана у всьому світі і широко використовується для оперативного оздоблення різноманітної продукції, персоналізації одягу, виготовлення фірмової символіки, сувенірів, тощо.
Сублимаційний термотрансферний друк ${ }^{3}$

Його сутність полягає у друкування зображення на проміжному носієві сублімаційними фарбувальними речовинами, після чого зображення переноситься на виріб за допомогою підвищеної температури й тискy.

Технологія сублімаційного друку використовує хімічний процес, при якому відбувається перехід фарбувальної речовини з твердого стану в газоподібний, без переходу в рідку фазу (що власне і називається процесом сублімації), з подальшою дифузією фарби в структуру поверхні матеріалу. У результаті отримують високоякісне стійке зображення.

\section{Технологія}

Спочатку необхідно створити макет із зображенням, що буде перенесене на виріб. Потім зображення наноситься в непрямому вигляді на сублімаційний папір за допомогою сублімаційного друку. Для цього використовують в більшій мірі струминні принтери або плоттери, адаптовані під сублімаційні фарбувальні речовини і в меншій мірі термопринтери, електрографічні, трафаретні, флексографічні та інші друкарські апарати.

В подальшому під впливом нагрівання й тиску зображення в термопресі переноситься на виріб (рис. 4). У випадку перенесення сублімаційних фарбувальних речовин на тканину, во-

\footnotetext{
3Sublimation transfer (Geo Knight \& Co, Sawgrass Technlogies), sublimation thermoprinting (Monti Antonio), sublimation heat transfer (BlackLightning). Taкож цю технологію називають Grawerton.
} 
на має бути синтетичною або напівсинтетичною (самі синтетичні волокна сублімують і утримують в собі барвник). Можна переносити зображення й на інші поверхні: натуральну тканину, кераміку, метал, стекло, дерево, пластик та інші матеріали, але вони повинні бути оброблені поліестеровим покриттям.

Під дією підвищеної температури сублімаційна фарба, перейшовши в газоподібний стан, проникає в поліестеровий шар. Таким чином отримане зображення знаходиться в самій структурі поліестеру і є дуже стійким до механічного та хімічного впливу.

\section{Матеріали}

В якості проміжного носія застосовується сублімаційний папір, поверхня якого виготовлена таким чином, що при друкуванні зображення вона мало вбирає

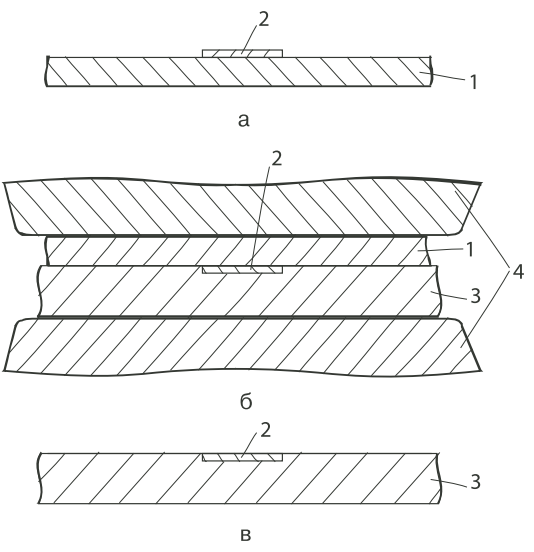

Рис. 4. Сублімаційний термотрансферний друк: а) трансфер: 1 - матеріал-основа, 2 - сублімаційна фарба; б) перенесення зображення у пресі: 1, 2 - див. (а), 3 виріб, 4 - термопрес; в) готовий виріб: 2, 3 - див. (б) фарбувальні речовини, дозволяючи потім зображенню практично повністю перейти в полімерний шар поверхні виробу. При цьому час висихання паперу абсолютно не великий.

Сублімаційні чорнила для струминних принтерів - це спеціальні пігментні фарбувальні речовини на водяній основі зі спеціальними властивостями: пігмент, під впливом тепла, перетворюється на пар, і на молекулярному рівні проникає в поліестер або покритий поліестеровою плівкою матеріал - метал, кераміку, скло, дерево та ін.

\section{Обладнання}

Для задруковування проміжного носія в сублімаційному термотрансферному друці переважно використовують струминні принтери чи плоттери, заправлені сублімаційним чорнилом. Також можливо застосовувати електрографічні (лазерні) принтери зі спеціальними картриджами для сублімаційного тонеру, трафаретний, флексографічний або офсетний друк. При цьому використовуються сублімаційні фарбувальні речовини, а сублімаційний папір задруковується на відповідному друкарському устаткуванні. Проте рентабельність використання цих видів друку не велика.

В сублімаційному термотрансферному друці в основному застосовуються преси великих форматів, як планшетні, так і каландрові. Для виготовлення виробів великих розмірів використовують переважно каландрові преси, які забезпечують необхідну зручність та швидкість процесу. 


\section{Застосування}

Технологія сублімаційного термотрансферного друку дозволяє отримати яскраві зображення з якістю, близькою до фотографічної. До того ж продукт буде стійким до дії впливу агресивних середовищ, УФ і т.д., оскільки фарбувальні речовини знаходяться в структурі поверхні виробу. Недоліком цієї технології $€$ можливість друкувати тільки на світлих поверхнях.

Термоперенесення текстильними плівками

Єдиної думки на рахунок того чи варто дану технологію відносити до термотрансферного друку немає (загалом, як і визначеності в назві).

А визначають ії в більшості випадків так, як і термотрансферний друк: це технологія перенесення зображення з проміжного носія на виріб під дією підвищеної температури й тискy.

В якості проміжного носія в термоперенесенні застосовуються спеціальні двошарові плівки. Розрізняють термоперенесення флекс (глянсова плівка) та флок (бархатиста плівка). Для обох випадків технологічний процес виглядає однаково.

\section{Технологія}

Спочатку необхідно виготовити макет у векторному графічному редакторі. Потім за допомогою ріжучого плоттера з плівки для термоперенесення вирізається виворітне зображення для перенесення (рис. 5). Сама плівка складається з двох шарів: прозорої полімерної основи і власне термоплівки. Ріжучий плоттер прорізає термоплівку, але не чіпає основу, тому після прорізування зображення не розсипається, а залишається на основі. Плоттер працює як звичайний принтер, тільки замість того щоб друкувати він ріже матеріал по заданому йому контуpy.

В подальшому з основи видаляються ті ділянки плівки, які переносити на продукт не потрібно і вона накладається на виріб в термопресі. Після прогрівання відокремлюється основа. Якщо необхідно нанести багатоколірне зображення, то процес повторюється 3 плівками інших кольорів.

\section{Матеріали}

Існує два основні види термоплівок: флекс (глянсові плівки) та флок (бархатисті плівки).

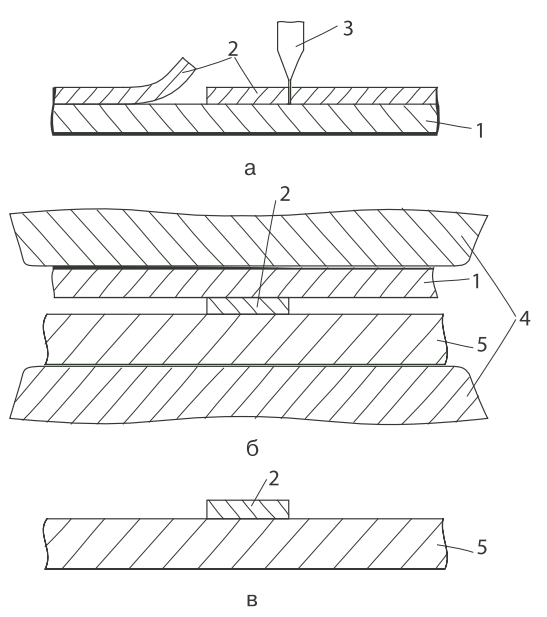

Рис. 5. Термоперенесення текстильними плівками: а) прорізування та відокремлення зайвої плівки: 1 - основа, 2 - термоплівка, 3 ніж плоттера; б) перенесення зоб-

раження у пресі: 1, 2 - див. (а), 4 - термопрес, 5 - виріб; в) готовий виріб: 2, 5 - див. (б)
(

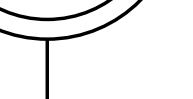


Плівка складається 3 двох шарів: прозорої основи і власне термоплівки зі спеціальним термоклеєм. Термоперенесення використовується тільки для текстильних виробів.

Текстильні плівки характеризуються гарною щільністю та еластичністю, що дозволяє переносити зображення на різної структури тканини. Якісні флекс плівки мають невелику товщину, тому нерідко складається враження, що зображення надруковане фарбами. Проте покривна здатність плівок більша, тому вони ідеально підходять зокрема для нанесення світлих зображень на темні тканини.

Флок - це плівка, покрита зверху ворсистим шаром, завдяки чому при нанесенні на виріб досягається ефект бархатy.

Також окрім глянсової та бархатистої фактури за допомогою термоплівок можна створювати світловідбиваючі, флуоресцентні, та інші зображення з різними ефектами, що допомагає зробити виріб унікальним і максимально ефектним.

\section{Обладнання}

Для даного способу друку в якості обладнання необхідно мати ріжучий плоттер та термопрес.

Ріжучі плоттери здатні прорізувати широкий спектр матеріалів, в тому числі й текстильні плівки флекс та флок. Механізм приводу рулонів плоттерів дозволяє різати по дуже довгим безперервним лініям без накопичення погрішності. А якісними плоттерами з ріжучим ножем більшого кута заточування, ніж звичайно, можна акуратно вирізати навіть дуже дрібні символи розміром 3-5 мм.

До термопресів висуваються ті ж вимоги, що і при термотрансферному друці.

\section{Застосування}

За допомогою термоперенесення текстильними плівками можна оздоблювати великий спектр текстильної продукції. Правильний вибір якісних плівок і дотримання технологічного процесу дозволяють створювати на текстилі зображення, які довго не стираються і не розтріскується під впливом температури, прасуванні та пранні. Проте для того, щоб за допомогою плівки виготовити зображення з дуже великою кількістю дрібних елементів потрібна дуже складна вибірка, дуже складне прорізування і це може займати багато часу.

Також при використанні плівок потрібно обмежуватися лише стандартною гамою кольорів. Неможливо отримати інші кольори, що забезпечується змішуванням фарби в інших способах друку.

\section{Термотрансферний спрей}

Дана технологія полягає у друкуванні зображення за допомогою електрографічного (лазерного) друку на звичайному папері, який потім покривається спреєм. В результаті отримуємо готове для перенесення в термопресі зображення. Але загалом ця технологія далеко не до- 
сконала. Річ у тому, що тонер після термоперенесення на продукт залишається на зовнішній стороні клейового шару спрея. У випадку звичайного термотрансферного паперу полімерний шар ламінує і накриває фарбувальну речовину, і вона знаходиться під захисним шаром, а тут - навпаки. В результаті продукт виходить нестійким до механічного та хімічного впливу.

Тому ця технологія хоча й існує певний період часу, але широкого застосування так і не знайшла.

\section{Висновки}

В ході роботи було проаналізовано технологічні особливості термотрансферного друку, розглянуто застарілі, сучасні та новітні способи друку, узагальнено та систематизовано ї різновиди.

Оскільки способи термотрансферного друку різняться за технологічним процесом, характеристиками матеріалів та обладнання, що зумовлюють якісне відтворення інформації, було виділено основні складові даних аспектів.

1. Зайчук В. В. Многокрасочные самоприклеивающиеся переводные изображения для оформления готовых изделий // Пятая Всесоюзная научно-техническая конференция по вопросам специальных видов печати: Тезисы докл. - К., 1976. - С. 123 - 124. 2. Лидова К. Н. Некоторые вопросы разработки термоприклеивающихся аппликаций // Шестая Всесоюзная научно-техническая конференция по специальным видам печати: Тезисы докл. - К., 1979. - C. 160 - 161. 3. Pat. GB 827313, IPC B44C1/17; $\mathrm{B} 44 \mathrm{C} 1 / 17$; EC B44C1/17H4. Improvements in or relating to transfer and similar materials / Inventor Reed Kenneth James; Applicant Associated Trapinex LTD Appl. No. GB19570001923 19570118; Priority No. GB19570001923 19570118; No. 1923/57. 4. Pat. GB 1320526, IPC B41M5/10; EC B41M5/10. Improvements in or relating to tissues for pressure transfer printing processes / Applicant Australia res lab - Appl. No. GB19700043025 19700908; Priority No. AU19690060875 19690915; №. 43025/70. 5. Дубовицький В. К. Матеріали для друкування самоприлипаючих перебивних зображень // Поліграфія i видавнича справа: Республ. міжвідомчий наук.-техн. збірн. - Л.: Вища школа, 1976. — № 12. - С. 34-41. 6. Пат. 467921 СССР, МКИЗ С09Ј3/12; C08D9/00. Клей (для переводных изображений) / В. К. Дубовицкий, С. А. Потиевская, Л. И. Войченко, А. А. Чуйко, В. А. Тертых и др. - № 1960620/23-5; Заяв. 29.08.73; Опубл. 25.04.75. Бюл. № 15; УДК 668.395.7 (088.8). 7. Пат. 484240 СССР, МКИЗ С09J3/12; C08D9/00. Клей, например, для переводных изображений / В. К. Дубовицкий, С. А. Потиевская, Л. И. Войченко, Э. А. Лебединская. - № 1963897/23-5; Заяв. 21.09.73; Опубл. 15.09.75. Бюл. № 34; УДК 668.395.7 (088.8). 8. Нечипорчук О. М., Розум Т. В. Тенденції розвитку технологій термотрансферного друку // Технологія і техніка друкарства. Зб. наук. пр. - К., 2007.- № $1-2-$ С. 56-59. 9. Нечипорчук А. Н. Термотрансферная печать. Обзор технологий // Print plus: бумага и полиграфия. - 2008. - № 1. - С. 64-69. 10. Киппхан Г. Энциклопедия по печатным средствам информации. Технологии и способы производства; Пер. с нем. - М.: МГУП, 2003. - С. 766-769. 11. Буковецкая О. А. Готовим в печать журнал, книгу, буклет, визитку. - М.: НТ Пресс, 2005. - 
C. 268-272. 12. Pat. US 20040197536, IPC B41M3/12; B05D1/36 USC 428/195.1; 427/146. Heat applied graphics and method / Inventor Stahl, Brett A. (Grosse Pointe Farms, MI, US) - Appl. No. 10/770144. 13. Goodridge M. Printing Plastisol Transfers [Electronic resource] // Union Ink Company. — Mode of access: WWW.URL: http://www.unionink.com/articles/transfer.html. - Last access: 2008. - Title from the screen. 14. Pat. EP 0479882, IPC B41M3/12; B41M5/035; B41M5/03; D06Q1/12; EC B41M5/025N; D06Q1/12. Verfahren zum ubertragen von Darstellungen auf eine Unterlage / Anmelder und Erfinder Hagedorn, Jurgen [DE/DE]; Frankfurter Strase 50, D-6072 Dreieich (De) Appl. No. EP19900910742 19900626; Priority No. DE19893920864 19890626; Pub. No. WO 91/00385. 15. Нечипорчук О. М. Термотрансферний друк // Друкарство молоде. Тези доп. міжнар. наук.-техн. конф. - К., 2007. Конф. 7. - С. 30-31. 16. Розум Т. В., Нечипорчук О. М. Вплив характеристик матеріалів на якість друкованої продукції у термотрансферному друці // Квалілогія книги. Зб. наук. пр., міжнар. наук.-практ. конф. - Л., 2007. Конф. 6. - С. 36-38. 